J. Perinat. Med. 10 (1982) 242

\section{Heart rate patterns in trisomic fetuses}

\author{
V. Kariniemi, P. Aula*
}

Departments I and II of Obstetrics and Gynecology, Helsinki University Central Hospital, Helsinki, Finland

\section{i: 1 Introduction}

Fetal heart rate (FHR) patterns in the well known human trisomy syndromes have not been comprehensively investigated. Incidental observations of abnormal oxytocin challenge tests in trisomy 21 [6] and 18 [4] have been reported. All three fetuses of these reports were delivered by cesarean section (CS). High CS rate on the other hand is a major concern in many obstetric units to-day. The significance of abnormal FHR pattern as an indication for CS is a widely discussed and disputed matter. The present study was prompted by the clinical experience that fetuses with trisomy frequently had abnormal FHR patterns and were delivered abdominally. Similar observations have recently been reported from elsewhere $[1,5]$.

\section{Material and methods}

\subsection{Pregnancies}

The material consisted of 29 trisomic fetuses delivered at Departments of Obstetrics and Gynecology, Helsinki University Central Hospital, during 1978-1980 among a total of 17421 deliveries. Three fetuses with trisomy 21 had such a labor that no electronic monitoring could be performed, one fetus with trisomy 18 was stillborn without antepartal FHR recording and cardio-

\footnotetext{
* Supported by The Foundation of Pediatric Research, Helsinki, Finland.
}

tocograms (CTG) of one fetus with trisomy 18 and of one fetus with trisomy 13 were lost. Hence, antepartal CTGs of fifteen fetuses with trisomy 21 (total recording time 57 hours 45 minutes), six fetuses with trisomy 18 (total recording time 80 hours five minutes) and of two fetuses with trisomy 13 (total recording time seven hours) were available for the study. Intrapartal CTGs were available of ten fetuses with trisomy 21 (recording time 32 hours 15 minutes) and of three fetuses with trisomy 18 (recording time five hours $15 \mathrm{~min}$ utes). A previously reported group of 55 normal pregnancies was used as an antepartal and 14 deliveries as an intrapartal control material [3].

Cesarean section was the mode of delivery in all cases of trisomy 13, in six out of the eight cases of trisomy 18 and in nine out of the eighteen cases of trisomy 21. An abnormal CTG was the main indication for all CS performed for fetuses with trisomy 18 and 13 and for six fetuses of nine with trisomy 21 .

\subsection{Cardiotocograms}

CTGs were evaluated visually by one of the authors (V.K.). The decelerations were classified according to HoN [2]. Silent pattern of FHR was recorded when the total variability was less than five beats per minute for more than five minutes. Accelerations were recorded when the heart rate accelerated from the baseline by more than 15 beats in less than 30 seconds. 


\subsection{Chromosome studies}

Karyotype analyses were performed on G-banded slides from PHA-stimulated lymphocyte cultures from peripheral blood samples. In some cases the blood sample was drawn by cardiac puncture after the death of the infant.

\subsection{Infants}

Clinical evaluation of the trisomic infants was made at the maternity wards in cases of trisomy 21 and at the neonatal care unit of the Childrens' Hospital in cases of trisomy 18 and 13. Both of the monitored 13-trisomic infants and four of the six monitored 18-trisomic infants died during the neonatal period. Autopsy was performed on all of these infants. Clinical findings, the pattern of dysmorphic features and congenital malformations were in good agreement with the trisomic karyotype in all cases, and in a majority of them the diagnosis was indisputable on the basis of clinical findings alone. None of the infants with trisomy 21 had symptomatic heart failure during the neonatal period nor other congenital malformations. Appropriate clinical data on infants with trisomy 18 and 13 are given in Tab. $I$.

\section{Results}

The incidence of antepartal FHR accelerations in fetal trisomy and control fetuses is shown in Fig. 1.

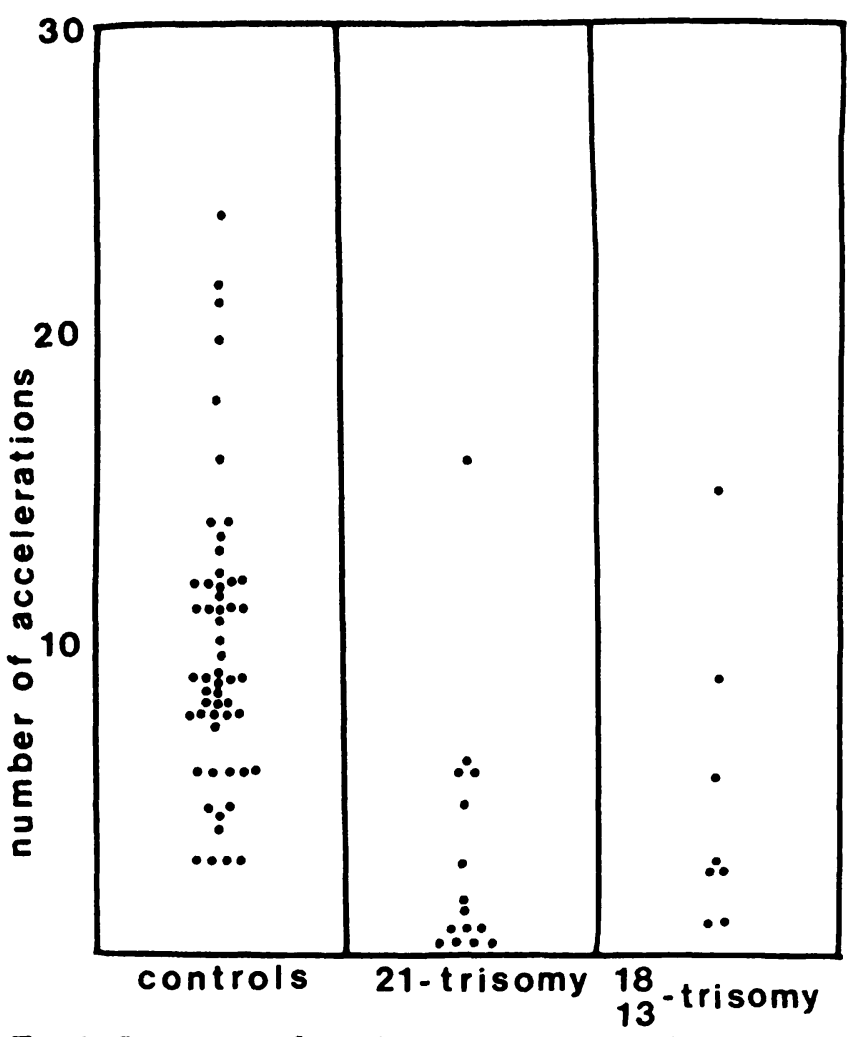

Fig. 1. Incidence of accelerations exceeding 15 beats per minute during 30 minute epochs of antepartal cardiotocograms of normal and trisomic fetuses. Differences were tested by Student's t-test: control-21, t-ratio 5.3, $\mathrm{p}<0.001$, control-18, 13, t-ratio $2.7, \mathrm{p}<0.05$; controltrisomies, t-ratio $5.5, \mathrm{p}<0.001$

Tab. I. Clinical data and autopsy findings of pregnancies with trisomy 18 and 13 which were monitored electronically.

\begin{tabular}{|c|c|c|c|c|c|}
\hline Case No. & $\begin{array}{l}\text { Birth- } \\
\text { weight } \\
\text { (grams) }\end{array}$ & $\begin{array}{l}\text { Gestational } \\
\text { age } \\
\text { (weeks) }\end{array}$ & $\begin{array}{l}\text { APGAR } \\
\text { score } \\
1-5 \text { min }\end{array}$ & $\begin{array}{l}\text { Antepartal } \\
\text { diagnosis }\end{array}$ & Cardiac findings \\
\hline Trisomy 18-1 & 2090 & 40 & $6-9$ & IUGR & $\begin{array}{l}\text { VSD, patent ductus arteriosus, hydro- } \\
\text { nephrosis unilateralis }\end{array}$ \\
\hline-2 & 2055 & $41+3$ & $5-4$ & Postmaturity & Omphalocele, cardiac murmur \\
\hline$=3$ & 2300 & $41+3$ & $2-8$ & $\begin{array}{l}\text { Hypertensio } \\
\text { gravid }\end{array}$ & Megalocardia \\
\hline-4 & 1310 & 38 & $3-8$ & $\begin{array}{l}\text { IUGR } \\
\text { Hydramnion }\end{array}$ & $\begin{array}{l}\text { VSD, atresia cesophagi, ren arcuatus, } \\
\text { agenesia cerebelli }\end{array}$ \\
\hline-5 & 970 & $30+4$ & $1-2$ & $\begin{array}{l}\text { IUGR } \\
\text { Pre-eclampsia }\end{array}$ & Patent ductus arteriosus \\
\hline-6 & 1310 & 35 & $2-5$ & $\begin{array}{l}\text { IUGR } \\
\text { Hypertensio gravid }\end{array}$ & $\begin{array}{l}\text { VSD, ren polycystica unilateralis, } \\
\text { hypersplenismus }\end{array}$ \\
\hline Trisomy $13-1$ & 1750 & $34+1$ & $6-9$ & $\begin{array}{l}\text { IUGR } \\
\text { Pre-eclampsia }\end{array}$ & $\begin{array}{l}\text { VSD, atresia valvulae pulm., } \\
\text { transpositio art., anomalia renum }\end{array}$ \\
\hline-2 & 1720 & $35+5$ & $7-7$ & Pre-eclampsia & $\begin{array}{l}\text { Infarctus placentae, truncus communis } \\
\text { anomalis, aplasia tractus olfact. }\end{array}$ \\
\hline
\end{tabular}

IUGR = intrauterine growth retardation $\mathrm{VSD}=$ ventricular septal defect 
Fetuses with trisomy had significantly fewer accelerations than had the normal fetuses. Decelerations and epochs of silent FHR pattern were not seen in antepartal CTGs of normal fetuses but were frequent during trisomic pregnancies (Tab.II), more frequent in trisomy 18 and 13 than trisomy 21. Intrapartal CTGs of the trisomic fetuses showed also less accelerations than did the controls (Tab. III). The control fetuses showed no epochs of silent patterns, while the trisomic fetuses had almost ten percent silent pattern in the intrapartal FHR. Late decelerations were more frequent in the trisomic than in the control fetuses. Variable decelerations were seen in equal numbers in the trisomic and control fetuses.

Tab. II. Numbers of decelerations and epochs of silent fetal heart rate pattern in antepartal cardiotocograms of six fetuses with trisomy 18 , two with trisomy 13,15 with trisomy 21 and of 55 control fetuses.

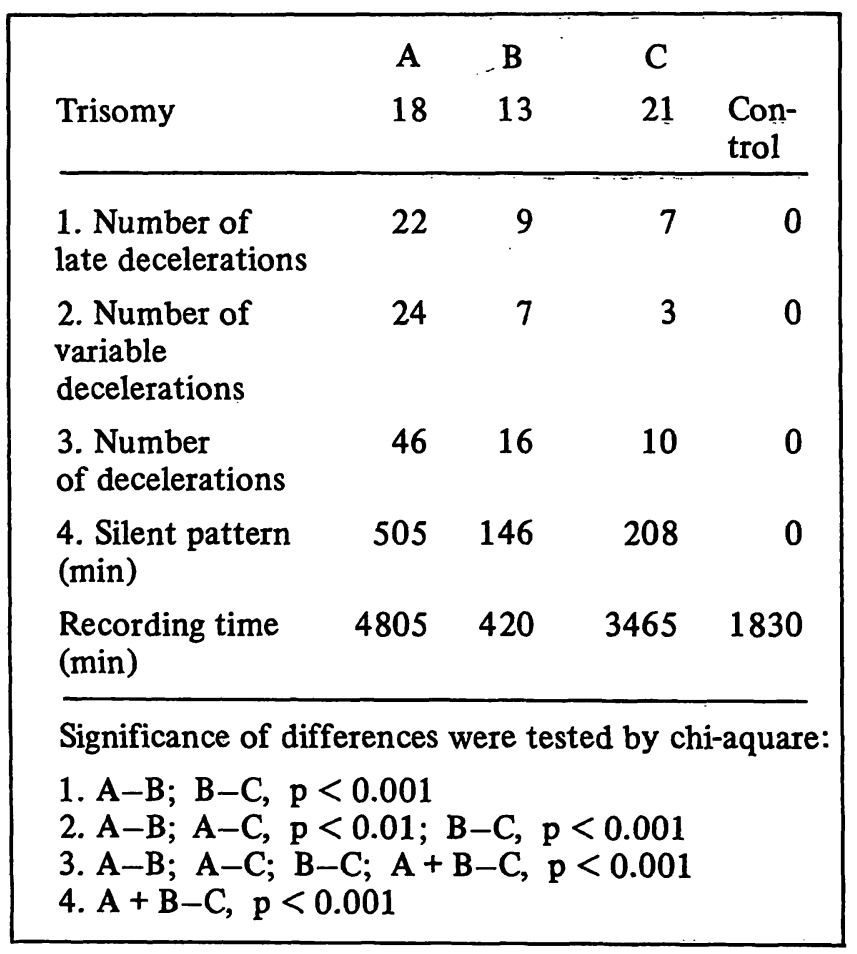

\section{Discussion}

The present study shows that FHR patterns of the trisomic fetuses are significantly different from those of normal fetuses. The accelerations, usually regarded as signs of fetal arousal level, were significantly fewer in ante- and intrapartal CTGs of trisomic fetuses than in CTGs of normal fetuses.
Tab. III. Numbers of accelerations and decelerations, epochs of silent fetal heart rate in intrapartal cardiotocograms of 14 normal fetuses, three with trisomy 18 and ten with trisomy 21 .

\begin{tabular}{|lrrr}
\hline & \multicolumn{1}{c}{ A } & \multicolumn{1}{c}{ B } & \multicolumn{1}{c}{ C } \\
& $\begin{array}{l}\text { Con- } \\
\text { trol }\end{array}$ & 18 & \multicolumn{1}{c}{21} \\
\hline $\begin{array}{l}\text { 1. Number of } \\
\text { accelerations }\end{array}$ & 541 & 40 & 185 \\
$\begin{array}{l}\text { 2. Number of late } \\
\text { decelerations }\end{array}$ & 33 & 5 & 77 \\
$\begin{array}{l}\text { 3. Number of variable } \\
\text { decelerations }\end{array}$ & 33 & 4 & 17 \\
$\begin{array}{l}\text { 4. Number of decelerations } \\
\begin{array}{l}\text { 5. Silent pattern (min) } \\
\text { Recording time (min) }\end{array}\end{array}$ & 66 & 9 & 94 \\
\hline
\end{tabular}

Significance of differences were tested by chi-square:

1. $A-C, A=B+C, p<0.001 ; A=B, p<0.02$

2. $\mathrm{A}-\mathrm{C}, \mathrm{A}-\mathrm{B}+\mathrm{C}, \mathrm{p}<0.001 ; \mathrm{B}-\mathrm{C}, \mathrm{p}<0.05$

4. $A-C ; A-B+C, p<0.001$

5. $\mathrm{A}-\mathrm{B}+\mathrm{C}, \mathrm{p}<0.001 ; \mathrm{B}-\mathrm{C}, \mathrm{p}<0.05$

This is an interesting phenomenon, and might be based on lower cortical activity among the trisomic fetuses. Antepartal decelerations of FHR, suggesting impairment of the umbilical and placental functions, were more frequent among the trisomic fetuses than among the controls. It is worth noting that two lethal trisomies (18- and 13-trisomy) showed even more decelerations than did the 21 trisomies. Intrapartal CTGs, on the other hand, did not show differences in the number of variable decelerations among the trisomies and controls. Epochs of silent FHR pattern were not seen among the intrapartal FHR recordings of the control fetuses, but were frequent among the trisomic fetuses, as in the antepartal period. Late decelerations occurred also more often among the trisomic than control fetuses.

The abnormal FHR patterns of trisomic pregnancies are similar to the abnormalities seen in other placental insufficiencies, and therefore, no characteristic FHR pattern for fetal trisomy can be delineated. Impairment of the fetoplacental function and the cardiac malformations frequently found in trisomic fetuses both probably contribute to the FHR changes. 
Seven mothers with fetal trisomy 18 or 13 and another seven mothers with fetal trisomy 21 in the present study had their first contact with the hospital more than three weeks before delivery. Fetal karyotyping from the amniotic fluid sample before the delivery would thus have been possible in some of these cases. Since a nonoptimal management of delivery in trisomy 21 hardly could be justified, only in seven cases an unnecessary CS could have been avoided by karyotyping amniotic fluid during three years. Moreover, the fairly long time, three to four weeks, required for cell culture and chromosome studies invalidates to a great extent the significance of the prenatal karyotyping. Most cesarean sections are performed by the indication of combined distress pattern of FHR, where decelerations and silent patterns are seen

\section{Summary}

A survey of the clinical records of fifteen fetuses with trisomy 21, six fetuses with trisomy 18 , and two fetuses with trisomy 13 was made in order to find out typical patterns of fetal heart rate (FHR) possibly associated with these conditions. Antepartal FHR patterns of 55 normal pregnancies and intrapartal FHR patterns of 14 normal labors were used as a control material. Trisomic fetuses showed significantly fewer FHR accelerations than did the controls. Fetuses with trisomy 18 and 13 had more antepartal decelerations than fetuses with trisomy 21 . Trisomic fetuses also showed more intrapartal late decelerations and epochs of silent FHR pattern than did the con-

Keywords: Fetal heart rate, fetal trisomy, fetus.

\section{Zusammenfassung}

Herzfrequenzmuster bei Feten mit Trisomien

Wir haben die klinischen Unterlagen von 15 Feten mit Trisomie 21, 6 Feten mit Trisomie 18 und 2 Feten mit Trisomie 13 aufgearbeitet, um möglicherweise typische Verteilungsmuster der fetalen Herzfrequenz (FHR) mit den genannten Krankheitsbildern korrelieren zu können. Als Kontrollmaterial dienten die antepartal aufgezeichneten FHR-Muster von 55 normalen Schwdngerschaften sowie die intrapartal registrierte FHR von 14 normalen Geburten. Bei Feten mit Trisomien traten signifikant weniger Akzelerationen als in der Kontrollgruppe auf. Feten mit Trisomie 18 und 13 hatten häufiger antepartale Dezelerationen als Feten mit Trisomie 21. Auch unter der Geburt hatten die Kinder mit Trisomie häufiger together, and this pattern rarely can be observed for longer than a couple of days. Evidently, a faster marker of lethal fetal trisomy than fetal karyotyping is urgently needed.

In conclusion, the combination of few accelerations, many decelerations and epochs of silent pattern of FHR, intrauterine growth retardation and possible oligo- or polyhydramnios at the end of second or at the onset of third trimester of pregnancy should arouse a suspicion of fetal trisomy. Fetal karyotyping from the amniotic fluid might in such cases be of practical value for identifying the lethal trisomies. If, however, the chromosome analysis is not available or does not show a lethal trisomy and if FHR patterns suggest fetal deterioration, an optimal management of the delivery is recommended. trols. The abnormal FHR patterns of the trisomic fetuses thus were similar to those in placental insufficiency. Cesarean section was performed for both fetuses with trisomy 13 , for five of the six fetuses with trisomy 18 and for nine of fifteen fetuses with trisomy 21 . In eleven of sixteen cesarean sections the main indication was abnormal cardiotocogram. Fetal karyotyping from an amniotic fluid sample should perhaps be considered when decelerations and silent patterns of FHR in a growthretarded, late second or early third trimester fetus are seen. In most cases, however, the decision for optimal management of labor must be based on FHR patterns solely.

Schlïsselwörter: Fetale Herzfrequenz, Trisomie beim Feten, Fetus.

J. Perinat. Med. 10 (1982)

Dezelerationen vom Spättyp sowie silente Perioden als die Kontrollgruppe. Die pathologischen FHR-Muster ähneln somit denen bei Plazentainsuffizienz. In beiden Fällen mit Trisomie 13, in 5 von 6 Fällen mit Trisomie 18 sowie in 9 von 15 Fällen mit Trisomie 21 wurde eine Sectio gemacht. Dabei war in 11 Fällen die Hauptindikation das pathologische CTG. Wenn Dezelerationen und silente Perioden bei einem wachstumsretardierten Feten gegen Ende des zweiten oder am Beginn des dritten Trimesters auftreten, kann eine Karyogramm nach Amniozentese indiziert sein. In den meisten Fällen jedoch sollten die Kriterien für eine optimale Geburtsleitung einzig und allein aus dem Verlauf der fetalen Herzfrequenz abgeleitet werden. 


\section{Résumé}

Aspects du rythme cardiaque des foetus trisomiques Les auteurs ont étudié-les enregistrements cliniques de 15 foetus trisomiques 21 , de 6 foetus trisomiques 18 et de 2 foetus trisomiques 13, afin de dégager des tracés typiques du rythme cardiaque foetal (RCF) éventuellement en rapport avec ces situations. Les enregistrements du RCF antépartum de 55 grossesses normales et du RCF en cours de travail de 14 accouchements normaux ont servi de contrôle. Les foetus trisomiques ont présenté significativement moins d'accélérations du RCF que les témoins. Les foetus trisomiques 18 et 13 ont plus de décélérations pendant la grossesse que les trisomiques 21 . Les foetus trisomiques présentent également en cours de travail plus de décélérations tardives et de périodes de

Mots-clés: Rythme cardiaque foetal, trisomie foetale, foetus. tracés plats que les témoins. Les anomalies du RCF des foetus trisomiques sont ainsi similaires à celles des insuffisances placentaires. Une césarienne a été pratiquée pour les 2 foetus trisomiques 13, pour 5 des 6 foetus trisomiques 18 et pour 9 des 15 foetus trisomiques 21 . Chez 11 des 16 césariennes, l'indication majeure a été posée sur des anomalies cardiotocographiques. Un cariotype foetal devrait peut-être être envisagé sur un échantillon de liquide amniotique devant des décélérations ou des portions de tracés plats chez des foetus hypotrophiques en fin du second trimestre ou au début du troisième. Dans la plupart des cas cependant la meilleure conduite à adopter lors du travail doit se fonder sur le rythme cardiaque foetal uniquement.

\section{Bibliography}

[1] GARITE, T. J., E. M. LINZEY, R. K. FREEMAN, W. DORCHESTER: Fetal heart rate patterns and fetal distress in fetuses with congenital anomalies Obstet. Gynec. 53 (1979) 716

[2] HON, E. H.: An introduction to fetal heart rate monitoring. New Haven, CT 1973

[3] KARINIEMI, V. P. ÄMMÄLÄ: Short term variability of fetal heart rate during pregnancies with normal and insufficient placental function. Amer. J. Obstet. Gynec. 139 (1981) 33
[4] KARP, L. E., P. J. MEIS: Trisomy 18 and antepartal fetal distress. J. Reprod. Med. 19 (1977) 345

[5] SCHNEIDER, A. S., M. T. MENNUTI, E. H. ZACKAI: High cesarean section rate in trisomy 18 births. Amer. J. Obstet. Gynec. 140 (1981) 367

[6] SPURRETT, B.: Stressed cardiotocography in late pregnancy. J. Obstet. Gynaec. Brit. Cwlth 78 (1971) 894

Received April 26, 1982. Accepted June 22, 1982.

V. Kariniemi, M.D.

Departments of Obstetrics and Gynecology

Helsinki University Central Hospital

Haartmanink. 2, 00290, Helsinki 29

Finland 